\title{
Monetary Aggregates and Price Stability in the BEAC Zone
}

\author{
MONDJELI MWA NDJOKOU \\ Faculty of Economics and Management \\ University of Yaoundé II- Soa, P.O. BOX 1365 Yaoundé- Cameroon \\ E-mail: motande@yahoo.fr \\ We acknowledge research support from the African Economic Research Consortium
}

\begin{abstract}
The main objective of this study is to evaluate the relevance of the use of monetary aggregates to achieve price stability in the BEAC zone. More precisely, the aim of the study is to examine the properties of stability, controllability and information content of monetary aggregates within the periods 1985- 2005 and 1992- 2005 using quarterly data. The econometric investigation leads to the following results: (a) the stability of monetary aggregates of the BEAC zone is verified; (b) the hypothesis of controllability of monetary aggregates is confirmed; (c) the contribution of monetary aggregates to the explanation of inflation is weak in short run and shows some improvement in the long run.
\end{abstract}

Keywords: Stability of monetary aggregates, Controllability of monetary aggregates, Information content of monetary aggregates.

\section{Introduction}

As a result of inflation pressures, monetary targeting policy became the key anchor of monetary policy of most Central Banks in Developed Countries during the 1970s. The usual relationship between monetary aggregates and the final objectives of monetary policy shift sharply during the middle 1970s and in the early 1980s due to innovations in the financial system. Opinions are divided between those for and against the use of monetary aggregates in the conduct of monetary policy. Friedman (1997) demonstrates that monetary aggregates are no more useful. According to McPhail (2000), the use of monetary targeting policy still makes sense since monetary aggregates fulfil the properties of stability, controllability and information content.

Since 1990, the final objective of price stability is explicitly defined in the BEAC zone. To achieve this final objective, monetary aggregates became the main focus of monetary policy strategy with the introduction of monetary programming (note 1). The data show that, since this period, the BEAC zone has been enjoying relative price stability. For about a decade, the inflation rate of the BEAC has been rotating between $0.5 \%$ and $6 \%$ with the highest rate of 5.9\% obtained in 1997 and the lowest rate, $0.5 \%$, in 1999 . However, some periods of inflationary tension are hidden behind this relative stability. This is the case with some countries that suffered from two digit inflation. Except the period of inflationary tension due to the devaluation of the CFA in 1994, countries like Chad and Congo record an inflation of $12.4 \%$ in 2001 and $16.6 \%$ in 1997 respectively. Equatorial Guinea has equally been suffering from a high inflation rate of $8.8 \%, 7.6 \%$ and $7.3 \%$ in 2001, 2002 and 2003 respectively. It is also important to emphasise that certain countries have sometimes experienced periods of negative inflation rates. This occurred in 1998 and 1999 in Central Africa Republic with inflation rates of $-1.9 \%$ and $-1.5 \%$ respectively. This has been also observed in Congo in 1998 (-1.6\%), 2000 (-0.34\%) and $2003(-0.2 \%)$; in Gabon and Chad in 1999 with inflation rates of $-0.7 \%$ and $-8 \%$ respectively.

Also, the conduct of monetary policy, since the reform of 1990, stresses two stylised facts. The first one highlights the gap between the announced monetary objectives and the realized one. Statistics show that the growth of money supply is $9 \%$ while the prevision is $1.5 \%$ in 1999 ; also, in the 2001, the prevision of money growth lies between $7.8 \%$ and $9.8 \%$ for a realisation of $7.1 \%$. The second stylised fact indicates the contrast between the variation of money supply and the evolution of inflation. In 1999 and 2000 for example, $\mathrm{M}_{2}$ had a growth rate of $19.45 \%$ and $18.06 \%$ respectively whereas inflation was at a level of $0.3 \%$ and $1.5 \%$. Then, we can observe that an increase of $9 \%$ in money supply leads to an inflation of $1.5 \%$. Moreover, we realise that a fall in the growth rate of money supply is not always followed by an equally fall in inflation. Between 2000 and 2001, the growth rate of $\mathrm{M}_{2}$ fell from $22.4 \%$ to $7.1 \%$ whereas the inflation rate moved from $1.5 \%$ in 2000 to $3 \%$ in 2002 .

The main objective of this study is to evaluate the relevance of the use of monetary aggregates to achieve price stability in the BEAC zone. More precisely, the aim of the study is to examine the properties of stability, controllability and information content of monetary aggregates.

The paper proceeds as follow. Section 2 provides a review of the literature. In section 3, we present the models used for the empirical verification. Section 4 describes the data of the study. In the fifth section, the main results of the study are presented and discussed. Section 6 concludes.

\section{Literature review}

Many studies have attempted to analyze the properties of monetary aggregates in the conduct of monetary policy. Two major features characterize the existing literature. On one hand, there is no study which looks at the three properties together. Except the work of Bordes and Marimoutou (2001), Serletis and Molik (2000) which deal with 
the question of stability and information content, the other studies look at the properties separately. On the second hand, the issue of empirical verification of the controllability of monetary aggregates is absent in the literature.

The stability of monetary aggregates is studied in the literature following many concepts and methods. In this sense, examine the stability of monetary aggregates refers as to look at the stability of money demand functions (Carlson and al, 2000), the stability of money velocity (Bordes and Marimoutou, 2001) or the stability of the relation between monetary aggregate and the final objectives of monetary policy (Estrella and Mishkin, 1997). The empirical methods used are one hand econometric using partial adjustment model, buffer stocks models and cointegration techniques. On the other hand, there are studies which used statistic test like chow test (Fielding, 1994), cusum test (Bahmani- Oskooee and Bohl, 2000) and Hansen test (Haug and Lucas, 1996). During the early of 1970s, the stability of monetary aggregates is well documented in the empirical literature. By the middle of the decennia, empirical studies conclude that money demand functions are instable and since then the results on the stability of monetary aggregates are mixed.

The empirical evaluation of the information content of monetary aggregates can be divided in two main streams. The first line of the research answer to the following question: can the variations of monetary aggregates cause the fluctuations of prices? While the second line focuses on the contribution of monetary aggregates in the evolution of inflation. Granger causality test (Gerlach and Svensson, 2003), correlation test (De Grauwe and Polan, 2001) and the estimation of a relation of cointegration (Serletis and Molik, 2000) are various approaches used to study the cause effect analysis. The cause effect approach does not give the real contribution of monetary aggregates in the variation of prices. Therefore, variance decomposition analysis gives more insight on this issue. We can enumerate two studies made in this line that is Roberds and Whiteman (1992) and Bordes and Marimoutou (2001).

\section{A brief description of estimation methodology}

\subsection{The stability of the relation between money and price stability: the empirical model}

The stability of monetary aggregates is verified by studying the stability of money velocity. In this sense, both univariate and multivariate approaches can be used. The appropriate method to estimate the univariate trend depends on the stationary properties of money velocity. Bordes and al (2007) argue that if money velocity is stationary, on can conclude that this variable is stable. According to the multivariate approach, the stability of the relation between money velocity and its determinants is studied using the technique of cointegration of Johansen (1988) and Johansen and Juselius (1990).

Following Bordes and Marimoutou (2001), the specification of the long-run relation between money velocity and its determinants is as follow:

$$
v_{t}=\alpha_{0}+\beta_{0} \text { inf }_{t}+\gamma_{0} r_{t}+u_{t}
$$

with $v_{t}$ : money velocity (in logarithm), $\pi_{t}$ : inflation (in logarithm) and $r_{t}$ : the main interest rate. Equation 1 is completed by equations which describe the short term relation between the variables.

Two steps are implemented for the empirical verification. The first step is to test the existence of a cointegrating relation between money velocity, inflation and the main interest rate using trace statistic test. If such relation exists, one proceeds to the estimation of the long run relation giving the expression of money velocity. The long run relation is completed by equations which describe the short term relation between the variables.

\subsection{The controllability of monetary aggregates}

The empirical verification of the controllability of monetary aggregates supposes the existence of a causal relationship between the monetary aggregate and the main interest rate. This is done by looking first at the cross coefficient correlation which measures how tight the relation is. Second, we use Granger causality test to indicate the effectiveness of the causal relationship.

\subsection{The evaluation of information content of monetary aggregates}

The empirical method to evaluate the information content of monetary aggregates is double. First, we examine the existence of a causal relationship between monetary aggregate and inflation using cross correlation coefficient and Granger causality test. Second, we check to what extent monetary aggregates can help to forecast prices using variance decomposition; this is made by using the methodology of Johansen (1988) and Johansen and Juselius (1990).

The Johansen and Juselius model (1990) has in this case three variables that are main interest rate, inflation rate and money growth. Three steps are followed by the Johansen (1988) and Johansen and Juselius (1990) procedure. The first one is to test of the hypothesis of the existence of one or more cointegration relations using trace statistic test. If the hypothesis cannot be rejected, we estimate the model which describes the long run relationship between growth rate of monetary aggregate, inflation rate and main interest rate (equation 5) and the short run relation between the variables. Finally, we use variance decomposition to evaluate the contribution of the monetary aggregates in explaining the general price level.

$$
\pi_{t}=\alpha_{0}+\beta_{0} r_{t}+v_{o} m_{t}+u_{t}
$$


The estimation of the VAR model leads to the variance decomposition analysis. Variance decomposition evaluates the contribution of the monetary aggregates in explaining the general price level.

\section{Data and sample period}

The variables used in the study are money velocity of $\mathrm{M}_{1}\left(\mathrm{~V}_{1} \mathrm{BEAC}\right)$ and $\mathrm{M}_{2},\left(\mathrm{~V}_{2} \mathrm{BEAC}\right)$, inflation (CPIBEAC), the main interest rate (TIDBEAC), monetary aggregate $\mathrm{M}_{1}\left(\mathrm{M}_{1} B E A C\right)$ and $\mathrm{M}_{2}\left(\mathrm{M}_{2} \mathrm{BEAC}\right)$. Inflation is approximated by consumer price index. Monetary aggregates used in the study are those composing the money supply of the BEAC. Money velocity $M_{1}$ is defined as the ratio between GDP and monetary aggregate $M_{1}$ and the money velocity of $M_{2}$ is obtained by dividing GDP by monetary aggregate $\mathrm{M}_{2}$. We use quarterly data and the statistics are obtained from IFS CD- ROM. Concerning data of GDP, we use the procedure of Goldstein and Khan (1976) to obtain quarterly data from annual data.

The sample period of the study lies within the periods 1985- 2005 and 1992- 2005 using quarterly data. This distinction in the sample period is made to show if the introduction of monetary programming has lead to significant change in the behaviour of monetary aggregates in the BEAC zone.

\section{Results and discussions}

The ADF test shows that the variables are non stationary in levels but they become stationary after first differencing.

\subsection{The stability of BEAC's monetary aggregates}

Figure 1 and figure 2 describe respectively the evolution of money growth rate and money velocity of the two monetary aggregates. Figure 1 show the evolution of $\mathrm{M}_{1}$ and $\mathrm{M}_{2}$ are similar. We can observe that the evolution of the money growth rate is laid within a band. This insight proves a certain stability in the evolution of the two monetary aggregates.

Figure 2 emphases the parallel evolution of money velocity of $\mathrm{M}_{1}$ and $\mathrm{M}_{2}$. They show a downward tendency since the first quarter of 1985. This reflects that the progression of monetary aggregate is faster than the one of GDP. This tendency is more accentuated from 1995 and reveals the monetization of the economy due to the amelioration of bank system in terms of number of bank and the confidence of economic agents.

Also, we observe that money velocity $\mathrm{M}_{1}$ and $\mathrm{M}_{2}$ deviate from the general trend between the first quarter of 1992 and the fourth quarter of 1994. This period coincide with the introduction of monetary programming and the devaluation of the CFA franc in January 1994. Except this temporary deviation, figure 2 shows that within the period, money velocity $\mathrm{M}_{1}$ and $\mathrm{M}_{2}$ are characterized by a stable evolution.

The econometric procedure begins with the test of the existence of one cointegrating relation between money velocity of each monetary aggregate, interest rate and inflation. The results show that there is no cointegrating relation between these variables between the first quarter of 1985 and the fourth quarter of 2005 . Therefore, the hypothesis of stability of money velocity of the two monetary aggregates is rejected. This conclusion is justified since figure 2 show a temporary instability in the behavior of monetary aggregates. According to the literature, a temporary instability does not compromise the long term stability of monetary aggregates. In order to take account this instability, we introduce a dummy variable which takes the value zero from first quarter of 1985 to fourth quarter of 1991 and one from first quarter of 1992 to the end of the period. The existence of one cointegrating relation is then established.

Table 1 presents the results of the estimation of the long run relation between money velocity $\mathrm{M}_{1}$, inflation and interest rate on one side and the estimation of the long run relation between money velocity $\mathrm{M}_{2}$, interest and rate inflation on the other side within the two periods of analysis. The results of error corrections models do not have particular comments here. Table 1 reveals that, the two explanatory variables that are inflation and interest rate have the expected sign. The acceleration of inflation, which is significant at $1 \%$, reduces the demand of cash and ceteris paribus increases the money velocity. An increase of the main interest rate, which have a positive impact on deposit interest rate, bring the economic agents to hold money in terms of saving and term deposits; the implication is a negative impact on money velocity of $\mathrm{M}_{2}$ ceteris paribus. The holding of more money in term of saving and deposits can lead to an increase in $\mathrm{M}_{1}$ 's monetary assets and explain ceteris paribus the decrease of money velocicy of $\mathrm{M}_{1}$. However, table 1 shows that the dummy variable is significant in the two regressions. The intuition behind this result is that the introduction of monetary programming has a significant impact on the evolution of money velocity of monetary aggregates. Bordes and al (2007), which study question the existence of a structural break in the evolution of monetary velocity in Euro zone, arrive to a similar result. After all, the results show that there exists one cointegrating relation between the different money velocity, inflation and the interest rate. We can then conclude on the stability of monetary aggregates of the BEAC.

The question is now to compare the stability of the two monetary aggregates $M_{1}$ and $M_{2}$ on one hand and the stability of the monetary aggregates within the two periods of analysis on the other hand. Table 2 shows that $\mathrm{M}_{2}$ is more stable within the two periods. In fact, the coefficient of variation of both the money growth rate and money velocity is weaker for $\mathrm{M}_{2}$. The theoretical background of this result is that substitution between monetary assets does not relatively affect the stability of large monetary aggregates. Looking at the result of the comparison of the stability of the monetary aggregates within the result shows that there is a paradox. In fact, when we are looking the 
coefficient of variation of the money growth rate, the monetary aggregates are more stable between the first quarter of 1992 and fourth quarter of 2005. If we refer to the results obtained by the money velocity, the stability of the aggregates is better on the other period. This paradox is justified in the sense that the ratio between GDP and monetary aggregates take into account both the incidence of GDP on monetary aggregate and the impact of monetary aggregate on GDP.

\subsection{The controllability of BEAC's monetary aggregates}

The result of cross correlation (table 3) shows that there is strong correlation between the main interest rate and the monetary aggregates within the period of analysis. The negative sign of the coefficient of correlation confirm theoretical prediction of the inverse relation between interest rate and money supply. The increase of the main interest rate is associated with a restrictive monetary policy. However, the coefficient of correlation is higher in the case of $\mathrm{M}_{1}$ in the two period of the sample. This result emphases that monetary authorities have a better control on narrow monetary aggregates as the theory has predicted. The comparison of the results within the period shows that, since the reform, the controllability of monetary aggregates is better. This result is justified in the sense that with the institution of monetary market, monetary authorities of the BEAC zone influence the quantity of the money in the economy by manipulating the main interest rate.

The Granger causality test permits to determine rigorously whether the relation between the main interest rate and the monetary aggregates $\mathrm{M}_{1}$ and $\mathrm{M}_{2}$ is tight. Table 4 gives the result of different Granger causality test and the results show that there is cause effect relation between the main interest rate the two monetary aggregates. In fact, the hypothesis of the non existence of causal relation is rejected at different level of significativity.

Thus, the results show that the two monetary aggregates can be controlled by the monetary authorities of the BEAC zone. This result is not surprising since, in the literature, the stability of monetary aggregates, as it's observed in the BEAC zone, implies the control of money supply by the manipulation of interest rates (Herwartz and Reimers, 2001).

\subsection{The information content of BEAC's monetary aggregates.}

The restitution of the results on the information content of BEAC's monetary aggregates is made following three ways. Firstly, we proceed to a graphical observation. Figure 3 describes the group of dots between inflation rate and monetary aggregate $\mathrm{M}_{2}$ (figure a) and between inflation rate and monetary aggregate $\mathrm{M}_{1}$ (figure $\mathrm{b}$ ). In general, we can observe a strong concentration of the points except a few of them which coincide with the high rate of inflation due to the devaluation of the CFA franc.

Secondly, cross correlation tests are tabulated (see table 5) and Granger causality test are run (table 6). The different values of cross correlation test are positive reflecting the classical theory of the existence of a positive relation between money growth and inflation. But the values are less than one. Therefore, there is not a proportional relationship between the variation of money supply and inflation. This result confirm the fact the relation between money and inflation is not strong in the countries where inflation is low (McCandless and Weber, 1995) as it's the case in the BEAC zone. However, coefficients of correlation obtained between the money growth rate of $\mathrm{M}_{2}$ and the inflation rate are higher than the one obtained between the money growth rate of $\mathrm{M}_{1}$ and inflation rate. Therefore, fluctuations of prices are more explain by the monetary aggregate $\mathrm{M}_{2}$. Concerning the period, table 5 shows that price fluctuations are more explained by the two monetary aggregates since the instauration of monetary programming. The intuition behind this result is that since the instauration of monetary programming there is an improvement in the information content of monetary aggregates. Table 6 describes the results of Granger causality test. At $5 \%$ of significativity, the null hypothesis of the test is rejected. The result shows that the two monetary aggregates Granger cause inflation. This conclusion is on the line with the quantitative theory of money and it's well documented in the literature.

Thirdly, we evaluate the contribution of monetary aggregates in the fluctuations of prices using variance decomposition analysis. The results of variance decomposition analysis are presented on table 7 . These results shows that the evolution of inflation is better explained as the time is going. This confirms the existence of lags in the conduct of monetary policy (note 3). In the short run, the qualities of monetary aggregates as indicator are worse. Within the first quarter of 1985 and the fourth quarter of 2005 , monetary aggregate $\mathrm{M}_{1}$ explain $10.11 \%, 14.22 \%$ and $22.15 \%$ of inflation respectively at a horizon of four, six and eight quarters. The variations of inflation due to monetary aggregates $\mathrm{M}_{2}$ are respectively $19.19 \%, 21.09 \%$ and $31.89 \%$ for the same horizon. These findings are the same with those of Roffia and Zaghini (2007), Assenmacher-Wesche and Gerlach (2006) which show that the capacity of prevision of monetary aggregate is weak in the short run.

The information content of monetary aggregate $\mathrm{M}_{2}$ is higher than the one of monetary aggregate $\mathrm{M}_{1}$ irrespectively of the period and the horizon. This result is justified since large monetary aggregates comprise more monetary assets than narrow monetary aggregates. It's then straightforward to think that the information content of $\mathrm{M}_{2}$ adds to the information content of $\mathrm{M}_{1}$ the one of quasi money. The study of McPhail (2000) reaches to the same result.

A comparison of the result within the two period of analysis highlights the fact the information contact of the monetary aggregates has not fundamentally improve with the adoption of monetary targeting policy. One justification is that the composition of monetary aggregates has not changed with the introduction of monetary 
programming. However, the variance decomposition analysis shows that, for the horizon relevant for the conduct of monetary policy, the qualities of monetary aggregates as indicators are better since the adoption of monetary targeting policy. This result make sense since, with the introduction of monetary programming, monetary authorities decide the quantity of money supply they put in the economy compatible with the objective of price stability.

In the long run, the ability of monetary aggregates to forecast the evolution of inflation improves. For example, between the first quarter of 1985 and the fourth quarter of 2005, the inflation rate is explained at thirty and forty quarters by monetary aggregate $\mathrm{M}_{1}$ respectively at $42.25 \%$ and $47.42 \%$. The percentages are $44.54 \%$ and $48.50 \%$ in the case of monetary aggregate $\mathrm{M}_{2}$. This improvement is justified by the fact that in the long run, money supply increases more rapidly than the GDP which traduce a high impact of money on the general price level.

\section{Conclusion}

The objective of this paper was to evaluate the relevance of use of monetary aggregates to achieve price stability in the BEAC zone. More precisely, the aim of the study is to examine the properties of stability, controllability and information content of monetary aggregates.

Looking at the stability of the monetary aggregates, the paper highlights the fact that the two monetary aggregates $\mathrm{M}_{1}$ and $\mathrm{M}_{2}$ of the BEAC are stable within the period of the study. Moreover, the monetary aggregates are more stable between the first quarter of 1992 and the fourth quarter of 2005. Also, $\mathrm{M}_{2}$ has a better stability within the two periods. The results confirm the hypothesis of controllability of BEAC's monetary aggregates. This controllability is better for the narrow monetary aggregate on one hand and since the adoption of monetary targeting policy. The evaluation of the information content emphasizes that the qualities of monetary aggregates in term of the explanation of price fluctuations are weak in the short run. But, there is some improvement in the long run. A comparison of the information content of $\mathrm{M}_{1}$ and $\mathrm{M}_{2}$ reveal that $\mathrm{M}_{2}$ explain more price fluctuations irrespective of the horizon and the period of analysis. Moreover, the paper highlights the fact that the information content of monetary aggregates has fundamentally improve with the introduction of monetary programming.

The main result of the study is that the use of monetary aggregates to achieve price stability in the BEAC zone is relevant. This result is confirmed by the fact that the empirical performances of monetary aggregates are improved with the introduction of monetary programming in 1992. However, monetary authorities of the BEAC should focus on the two monetary aggregates $\left(\mathrm{M}_{1}\right.$ and $\left.\mathrm{M}_{2}\right)$ since in terms of controllability, $\mathrm{M}_{1}$ has better empirical results.

\section{References}

Assenmacher-Wesche, K. \& Gerlach, S. (2006). Understanding the link between money and inflation in the Euro area. CEPR Discussion Paper, $\mathrm{n}^{\circ} 5683$.

Bahmani- Oskooee, M. \& Bohl, M. T. (2000). German monetary unification and the stability of the German M3 money demand function. Economics Letters, vol. 66, n 2, 203- 208.

Bordes, C. Clerc, L. \& Marimoutou, V. (2007). Is there a structural break in equilibrium velocity in the euro area?. Notes d'Etudes et de Recherche, Banque de France n' 165, 1- 34.

Bordes, C. \& Marimoutou, V. (2001). Les Propriétés des agrégats monétaires: stabilité et contenu en Information, analyse du cas Français (1978- 1998) et enseignements pour la Zone Euro. in Gaffard J.L. et Glais M., Monnaie, Croissance et Marché, Essai en l'Honneur de Jacques Le Bourva, Paris, Economica, 117- 166.

Carlson, J. B. Hoffman, D. L. Keen, B. D. \& Rasche, R. H. (2000). Results of a study of the stability of cointegrating relations comprised of broad monetary aggregates. Journal of Monetary Economics, vol. 46, n 2, 345- 383.

Estrella, A. \& Mishkin, F.S. (1997). Is there a role for monetary aggregates in the conduct of monetary policy?. Journal of Monetary Economics, vol. 40 (2), 279-304.

Fielding, D. (1994). Money demand in four African countries. Journal of Economics Studies, vol. 21, n 2, 3- 37.

Fischer, S. Sahay, R. \& Vegh, C. A. (2002). Modern hyper and high inflations ». Journal of Economic Literature, vol. 40(3), 837- 880 .

Friedman, B.M. (1997). The Rise and the fall of money growth targets as guidelines of U.S monetary policy. Journal of Monetary Economics, vol. 4(3), 279- 304.

Goldstein, M. \& Khan, M. S. (1976). Large versus small price changes and the demand for imports. IMF Staff Papers, vol. 23, 200-225.

Haug, A. \& Lucas, R. F. (1996). Long- term money demand in Canada: In search of stability. The Review of Economics and Statistics, vol. 78, $\mathrm{n}^{\circ}$ 2, 345- 348.

Herwartz, H. \& Reimers, H. E. (2001). Long- run links among money, prices and output: World- wide evidence. Economic Research Centre of the Deutsche Bundesbank, Discussion Paper, $\mathrm{n}^{\circ} 14$.

Johansen, S. \& Juselius, K. (1990). Maximum likelihood estimation and influence on cointegration with application to the demand of money. Oxford Bulletin of Economics and Statistics, vol. 52 (2), 169-210.

Johansen, S. (1988). Statistical analysis of cointegration vectors . Journal of Economic Dynamics and Control, vol. 12 (2-3), 231-254. 
McCandless, G. T. \& Weber, W. E. (1995). Some monetary facts. Federal Reserve Bank of Minneapolis Quarterly Review, vol.19(3), 2- 11.

McPhail, K. (2000). L'utilité de la monnaie au sens large pour la conduite de la politique monétaire. in La Monnaie, La Politique Monétaire et Les Mécanismes de Transmission, Actes du Colloque Tenu à la Banque du Canada en Novembre 1999, Ottawa, Banque Du Canada, 61-98.

Mondjeli, M. N. (2008). Les propriétés des agrégats de monnaie de la Banque des Etats de l'Afrique Centrale. Thèse de Doctorat Ph.D. Université de Yaoundé II-Soa.

Roffia, B. \& Zaghini, A. (2007). Excess money growth and inflation dynamics. European Central Bank, Working Paper, $\mathrm{n}^{\circ}$ 749.

Serletis, A. \& Molik, T. E. (2000). Les agrégats monétaires et politique monétaire. in La Monnaie, La Politique Monétaire et Les Mécanismes de Transmission, Actes du Colloque tenu à La Banque du Canada en Novembre 1999, Ottawa, Banque du Canada, 121-156.

\section{Notes}

Note 1 . With the introduction of monetary programming, monetary aggregates became the intermediate targets in the conduct of monetary policy of the BEAC, especially $\mathrm{M}_{2}$.

Note 2. Granger $(1983,1986)$ shows that the stability of a long run equilibrium relationship is equivalent to the concept of cointegration.

Table 1. Results of the estimation of the long- run relation between money velocity, inflation and interest rate.

\begin{tabular}{|c|c|c|c|c|c|c|c|c|}
\hline \multirow{2}{*}{ 1985Q1- 2005Q4 } & \multicolumn{4}{|l|}{$\mathrm{V}_{1} \mathrm{BEAC}$} & \multicolumn{4}{|l|}{$\mathrm{V}_{2} \mathrm{BEAC}$} \\
\hline & Coef. & Std. & $\mathrm{z}$ & $\mathrm{P}>|\mathrm{z}|$ & Coef. & Std. & $\mathrm{z}$ & $\mathrm{P}>|\mathrm{z}|$ \\
\hline CPIBEAC & $0.734803(*)$ & 0.1468371 & 5.00 & 0.000 & $1.41495(*)$ & 0.3632868 & 3.89 & 0.000 \\
\hline TIDBEAC & $-0.175003(*)$ & 0.0290307 & -6.03 & 0.000 & $-0.2997721(*)$ & 0.071861 & -4.17 & 0.000 \\
\hline DUMMY & $-0.470121\left(^{*}\right)$ & 0.1259607 & -3.73 & 0.000 & $-0.714866(* *)$ & 0.3174359 & -2.25 & 0.024 \\
\hline \multirow{2}{*}{ 1992Q1- 2005Q4 } & \multicolumn{4}{|l|}{$\mathrm{V}_{1} \mathrm{BEAC}$} & \multicolumn{4}{|l|}{$\mathrm{V}_{2} \mathrm{BEAC}$} \\
\hline & Coef. & Std. & $\mathrm{z}$ & $\mathrm{P}>|\mathrm{z}|$ & Coef. & Std. & $\mathrm{z}$ & $\mathrm{P}>|\mathrm{z}|$ \\
\hline CPIBEAC & $0.173882(*)$ & 0.0382482 & 4.55 & 0.000 & $0.3693087(*)$ & 0.0892466 & 4.14 & 0.000 \\
\hline TIDBEAC & $-0.056681(*)$ & 0.0096456 & -5.88 & 0.000 & $-0.0856097(*)$ & 0.0223742 & -3.83 & 0.000 \\
\hline
\end{tabular}

$(*),(* *)$ and $(* * *)$ represent the level of significativity of the variables respectively at $1 \%, 5 \%$ and $10 \%$.

Table 2. Mean, standard deviation and coefficient of variation of money growth rate and money velocity

\begin{tabular}{|l|lll|lll|}
\hline & 1985Q1-2005Q4 & & 1992Q1-2005Q4 & \\
\cline { 2 - 7 } & Mean & $\begin{array}{c}\text { Standard } \\
\text { deviation }\end{array}$ & $\begin{array}{l}\text { Coef. of } \\
\text { variation }\end{array}$ & Mean & $\begin{array}{c}\text { Standard } \\
\text { deviation }\end{array}$ & $\begin{array}{c}\text { Coef. of } \\
\text { variation }\end{array}$ \\
\hline $\mathrm{M}_{1}$ BEAC & 1.309489 & 5.005784 & 3.8228 & 1.885846 & 5.67215 & 3.0077 \\
$\mathrm{M}_{2}$ BEAC & 1.133753 & 3.829617 & 3.3779 & 1.672964 & 4.157124 & 2.4849 \\
$\mathrm{~V}_{1}$ BEAC & 1.348875 & 0.249402 & 0.1848 & 1.278139 & 0.278349 & 0.2177 \\
$\mathrm{~V}_{2}$ BEAC & 0.858988 & 0.132527 & 0.1542 & 0.828664 & 0.150512 & 0.1816 \\
\hline
\end{tabular}

Table 3. Results of the correlation test between the main interest rate and the monetary aggregates $M_{1}$ and $M_{2}$

\begin{tabular}{|l|l|l|l|l|}
\hline & \multicolumn{3}{|l|}{ 1985Q1-2005Q4 } & 1992Q1- 2005Q4 \\
\hline & M1BEAC & M2BEAC & M1BEAC & M2BEAC \\
\hline TIDBEAC & -0.8034 & -0.7842 & -0.8216 & -0.7910 \\
\hline
\end{tabular}

Table 4. Results of the Granger causality test between the main interest rate and the monetary aggregates $\mathrm{M}_{1}$ and $\mathrm{M}_{2}$

\begin{tabular}{|l|ll|}
\hline Null Hypothesis: & F-Statistic & Probability \\
\hline TIDBEAC does not Granger Cause M1BEAC & 0.29485 & 0.58864 \\
TIDBEAC does not Granger Cause M2BEAC & 0.10462 & 0.74720 \\
\hline TIDBEAC does not Granger Cause M1BEAC & 0.51050 & 0.47806 \\
TIDBEAC does not Granger Cause M2BEAC & 0.44581 & 0.50723 \\
\hline
\end{tabular}


Table 5. Results of cross correlation test between money growth and inflation rate.

\begin{tabular}{|lllll|}
\hline & \multicolumn{2}{l|}{ 1985Q1-2005Q4 } & \multicolumn{2}{l|}{ 1992Q1- 2005Q4 } \\
\hline & M1BEAC & M2BEAC & M1BEAC & M2BEAC \\
\hline Taux d'inflation & 0.3402 & 0.4142 & 0.3602 & 0.4424 \\
\hline
\end{tabular}

Table 6. Results of the Granger causality test between monetary aggregates $M_{1}$ and $M_{2}$ and inflation

\begin{tabular}{|l|l|l|}
\hline Null Hypothesis: & F-Statistic & Probability \\
\hline M1BEAC does not Granger Cause CPIBEAC & 1.40477 & 0.24140 \\
M2BEAC does not Granger Cause CPIBEAC & 1.10108 & 0.36298 \\
\hline M1BEAC does not Granger Cause CPIBEAC & 0.06242 & 0.93956 \\
M2BEAC does not Granger Cause CPIBEAC & 1.23164 & 0.31031 \\
\hline
\end{tabular}

Table 7. Results of variance decomposition analysis

\begin{tabular}{|l|ll|ll|}
\hline \multirow{2}{*}{ Horizon } & \multicolumn{2}{|l|}{1985 Q1- 2005Q4 } & \multicolumn{2}{l|}{ 1992Q1-2005Q4 } \\
\cline { 2 - 5 } & M1BEAC & M2BEAC & M1BEAC & M2BEAC \\
\hline 1 & 7.362880 & 11.75009 & 18.81588 & 23.80654 \\
4 & 10.11892 & 19.19529 & 12.77472 & 19.20553 \\
6 & 14.22271 & 21.0915 & 14.22881 & 22.14099 \\
8 & 22.15080 & 31.89268 & 20.40403 & 31.91070 \\
10 & 27.28112 & 34.81000 & 24.35053 & 33.99147 \\
20 & 35.39091 & 39.85769 & 30.33624 & 38.28488 \\
30 & 42.25608 & 44.54431 & 35.77442 & 42.18187 \\
40 & 47.42708 & 48.50881 & 40.19111 & 45.54975 \\
\hline
\end{tabular}

Figure (a)

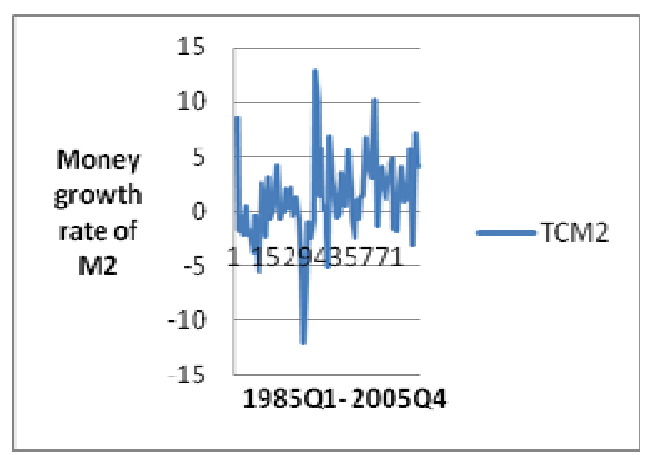

Figure (b)

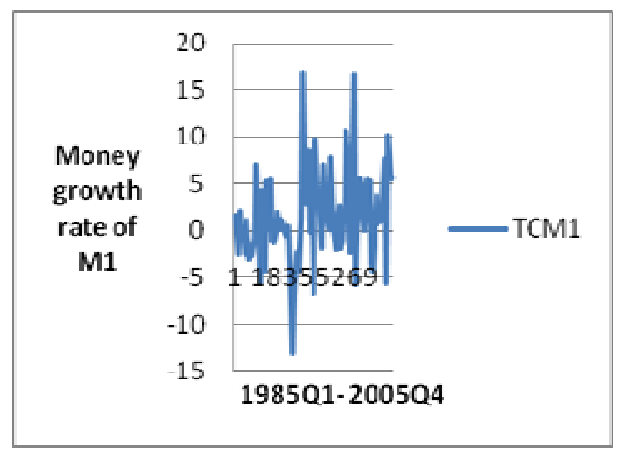

Source: Author

Figure 1. Evolution of money growth rate M1 and money growth rate M2 in the BEAC zone from 1985 to 2005 using quarterly data 


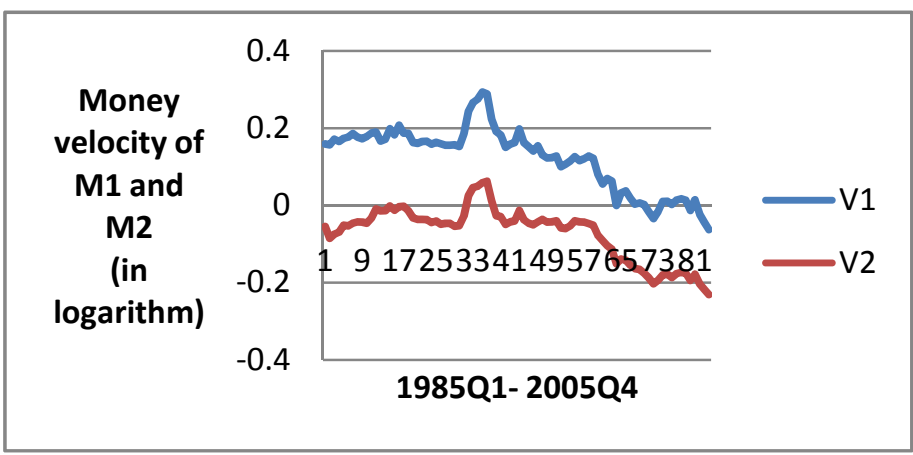

Source: Author

Figure 2. Evolution of money velocity M1 et money velocity M2 in the BEAC zone from 1985 to 2005 using quarterly data

Figure (a)

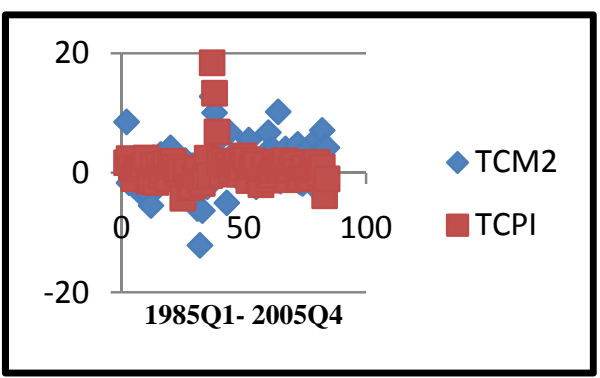

Source: Author
Figure (b)

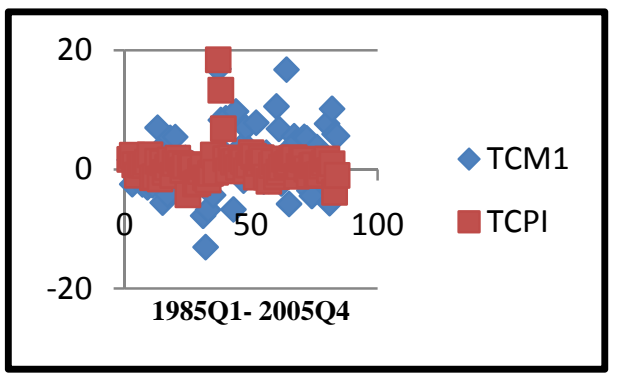

Figure 3. Evolution of inflation rate and money growth rate of M1 and money growth rate of M2 (group of dots) 